\title{
Extract of bacterial strain isolated from cave in the eastern Amazon induces selective cytotoxicity on tumor line of murine melanoma
}

Extrato de cepa bacteriana isolada de caverna da Amazônia Oriental induz citotoxicidade seletiva sobre linhagem tumoral de melanoma murino

\author{
R. S. Santos ${ }^{1}$; U. B. Albino ${ }^{*} ;$ K. S. Paludo ${ }^{2}$; S. Y. Simote Silva ${ }^{1}$; M. N. Oliveira1; \\ D. A. Santos ${ }^{1}$; A. M. R. Marinho ${ }^{3}$; P. S. B. Marinho' ; T. C. Lima'; G. F. N. \\ Santos $^{2}$; G. Sequinel ${ }^{1}$; S. C. Silva ${ }^{1}$ \\ ${ }^{1}$ Faculdade de Química/Laboratório de microbiologia, Universidade Federal do Sul e Sudeste do Pará, 68505-080, \\ Marabá-Pará, Brasil \\ ${ }^{2}$ Universidade Estadual de Ponta Grossa, 84030-900, Ponta Grossa-Paraná, Brasil \\ ${ }^{3}$ Faculdade de Química/LAbiomi, Universidade Federal do Pará, 66075-110, Belém-Pará, Brasil. \\ *ualbino@unifesspa.edu.br \\ (Recebido em 16 de outubro de 2020; aceito em 08 de fevereiro de 2021)
}

\begin{abstract}
Cancer is one of the most deadly diseases in the world, being related to the disordered growth of defective cells which produces harmful substances to the body. In this context, one of the great challenges of science is finding an effective bioactive compound for treating of this disease and microorganisms from restrictive environments, such as caves, are indicated as a promising source of these compounds. The objective of this work was to evaluate the extracts cytotoxic effects obtained from cultures of two bacterial strains isolated from Pedra da Cachoeira cave, Altamira-PA, located in a preserved forest fragment in the Eastern Amazon. Bacteria were identified by DNA sequencing analysis encoding ribosomal RNA. The choice of the ideal period of microbial development, aiming at the biocompounds production, was based in a kinetic study realized from a growth curve. Organic extracts were produced after 30 hours (stationary phase) and 40 hours (decline phase) of cultivation, obtaining four extracts by liquid - liquid partition of culture medium and four extracts from the bacterial cells. In vitro cytotoxicity tests were performed with B16F10 tumor cells using the MTT method. From the phylogenetic analyzes of the DNA sequences of both strains, a cluster with the species Bacillus subtilis was verified. The extracts obtained were subjected to cytotoxic assays and their cell viability was evaluated based on the minimum inhibitory concentration (IC50) and selectivity index (IS), with the CV26AI30H extract having an IC50 value of 83.99 and IS greater than 4.70.
\end{abstract}

Keywords: cancer, extreme environments, Bacillus subtilis

Câncer é uma das doenças que mais matam no mundo, relacionado ao crescimento desordenado de células defeituosas que produzem substâncias nocivas ao organismo. Um dos grandes desafios da ciência é encontrar compostos bioativos efetivos para o tratamento dessa doença e microrganismos de ambientes restritivos, como cavernas, apresentam-se como uma fonte promissora desses compostos. O objetivo deste trabalho foi avaliar os efeitos citotóxicos dos extratos obtidos das culturas de duas linhagens bacterianas isoladas da caverna Pedra da Cachoeira, Altamira-PA, localizada em fragmento florestal preservado da Amazônia Oriental. As bactérias foram identificadas por análise de sequenciamento de DNA codificante do RNA ribossomal. Para a escolha do período ideal de desenvolvimento microbiano, visando a produção de biocompostos, foi feito um estudo cinético de produção de metabolitos a partir de uma curva de crescimento. Foram produzidos extratos orgânicos após 30 horas (fase estacionária) e 40 horas (fase de declínio) de cultivo, obtendo-se quatro extratos por partição líquido - líquido do meio de cultivo e quatro extratos a partir das células bacterianas. Dos mesmos foram realizados ensaios de citotoxicidade in vitro em células tumorais B16F10 via método MTT. A partir das análises filogenéticas das sequências de DNA de ambas as linhagens, foi verificado agrupamento com a espécie Bacillus subtilis. Os extratos obtidos, foram submetidos aos ensaios citotóxicos e sua viabilidade celular foi avaliada a partir da medida de concentração inibitória mínima (CI50) e índice de seletividade (IS), tendo-se o extrato CV26AI30H com o valor de CI50 de 83,99 e IS maior que 4,70 .

Palavras-chave: câncer, ambientes extremos, Bacillus subtilis 


\section{INTRODUCTION}

Among the most deadly diseases in the world, there is cancer. From various origins, it is considered the second non-transmitted disease in dominance. According to a recent study [1], 18 million people were affected by cancer in 2018, and 9.6 million died of this disease. The study also predicts that 22 millions of new cases will emerge in the incoming decades and 13 million people will die each year. Incidence of this disease was more common in developed countries, however, today it is present in all countries. Two-thirds of cancer deaths worldwide currently occur in countries with low or middle income [2]. In Brazil, it is considered the second leading cause of death [3] and at least 35\% of cancer cases are due to behavioral risk factors and persistent infections. The cancer consists of a chronic disease, characterized by the disordered growth of cells forming tumors that produce harmful substances to the body and can lead the individual to death [4].

Thereby, one of the great challenges of science is finding new substances capable of combating this irregular growth [5]. A possibility are bacteria from the most different environments. This microorganisms have been explored by the pharmaceutical industry due to their ability to produce a variety of new drugs from its secondary metabolites, emphasizing antitumor activity compounds [6]. Also known as natural products, secondary metabolites are small organic molecules that have diverse biological activities and are often quite potent [7].

Atypical environments microorganisms, which live in extreme situations or under few resources, present themselves as a promising source of these metabolites synthesis. Between these microorganisms, the cave bacteria stand out. Cave environments are poorly studied from a microbiological point of view. The physical isolation associated with the unique characteristics of the cave environment provides a singular microbial habitat, with different evolutionary pressures from the surface and, with that, there is a propensity to new compounds development and/or new metabolic routes [8]. There is a tendency among researchers to believe that the combination of oligotrophy with the metals presence interferes with the DNA and the great competition between organisms in cave environments favor the production of compounds that inhibit competitors metabolism with possible actions on tumor cells. Cave bacteria of the Streptomyces genus [9] have already become known for the activities of their compounds.

In this work, extracts of two bacteria isolated from the Pedra da Cachoeira cave (Pará - Brazil) were analyzed for their cytotoxic activities for murine melanoma B16F10 tumor cells. This cave has tourist potential and is located in a preserved fragment of the Eastern Amazon Forest. It was already reported in the 1990s by fauna researchers [10], but it remains an under-studied environment with great scientific potential.

\section{MATERIAL AND METHODS}

\subsection{Bacterial strains characterization and identification}

The bacteria studied in this work were isolated during an environmental microbiology study carried out in 2014. They were cultivated from material samples collected in the Pedra da Cachoeira cave, located in the municipality of Altamira-PA ( $03^{\circ} 18^{\prime} 43^{\prime}$ ' S e $52^{\circ} 20^{\prime} 28^{\prime \prime} \mathrm{W}$ ). The samples were collected on the walls, soil and mounds of guano in the middle portion of the cave, aseptically and taking care not to damage the environments, and showed high antimicrobial activity [11]. Bacterial colonies were initially characterized by their cell morphology, microscopy against Gram staining and presence of capsules and the endospores production. From these observations, the strain identified as CV26, was selected for study. The CV26 strain was composed of two different bacteria, with small variations in cell morphology and reflected in the colonies appearance. They were separated, and then recoded as CV26A and CV26B, so they were evaluated for potential in the compounds production apart. Samples of the two strains were sent for identification, to the PLURIDISCIPLINARY CENTER FOR CHEMICAL, BIOLOGICAL AND AGRICULTURAL RESEARCH at the State University of Campinas, São Paulo (UNICAMP-SP) with the process number: CPQBA 1951/19 DRM. Sequence analysis of 16S rRNA region genes was applied to them. Once the sequences were obtained, they were analyzed by pairing with sequences deposited 
in the database ncbi. The colonies were cultivated and genomic DNA was subsequently extracted using the phenol extraction based protocol [12]. Partial amplification of the RNAr 16s gene from the culture was performed by PCR methodology, using the extracted genomic DNA as a template. The primers (synthetic oligonucleotides) used for the PCR reaction were 10f and 1100r. Amplification product was purified in column (GFX PCR DNA and Gel Band purification kit, GE Healthcare) and subjected directly to sequencing using the ABI 3500XL Series automatic sequencer (Applied Biossystems).

\subsection{Genetic Distance Analysis}

The partial sequences of the RNAr 16s gene obtained with the different primers were assembled in a contig (unique consensus sequence combining the different fragments obtained) and compared with the organism sequences represented in the Genbank database and the RPD. Sequences of microorganisms related to the unknown bacteria were selected for the dendrogram construction. DNA sequences were aligned using the CLUSTAL X program [13], inserted in the bioEdit 7.2.6 software [14]. The genetic distance analyzes were conducted using the MEGA version 6.0 program [15]. Distance matrix was calculated with the Kimura model [16] and the dendrogram construction from the genetic distances was performed using the Neighobor-Joining model [17], with bootstrap values calculated from 1000 re-samples, with the software included in the MEGA 6.0 program.

\subsection{Kinetic study for choosing extraction time}

To choose the best extraction time, a kinetic study was made using a growth curve, from the two bacterial strains, CV26a and CV26b, observing the four phases of bacterial growth: lag, log, stationary and phase of decline [18]. The bacteria were reactivated in Luria-Bertani medium with agar (solid). For the growth curve construction, they were grown in $100 \mathrm{~mL}$ of sterile Luria-Bertani liquid medium for 44 hours in a SQ Lab Model SL 223 refrigerated shaker incubator, under $30^{\circ} \mathrm{C}$ temperature and $120 \mathrm{rpm}$ constant agitation. During the cultivation period, a $0.5 \mu \mathrm{L}$ aliquot was removed every 2 hours and added to Petri dishes containing solid Luria-Bertani medium and spread with a Drigalski loop where the cells were counted macroscopically, according to the colonies number observed. This phase was divided into 26 experiments that composed a growth curve. The ideal cultivation moment and extraction time were determined from this growth curve.

\subsection{Obtaining Bacterial Extracts}

Two moments were chosen for large-scale cultivation and obtaining of bacterial extracts from the kinetic study. For the extracts production, the bacteria were grown in Luria-Bertani liquid medium and taken to a refrigerated shaker incubator (Model S1 223, Solab, Piracicaba-SP, Brazil) with a temperature of $30^{\circ} \mathrm{C}$ and constant agitation of $120 \mathrm{rpm}$ during 30 hours and 40 hours. After these periods, they were filtered using a vacuum pump (Model Q955B, Quims, Diadema-SP, Brazil) to separate the cells from the liquid medium. Then, a liquid-liquid partition of the liquid part was made with ethyl acetate, where $120 \mathrm{ml}$ ethyl acetate were used for each liter of medium, the solid part extractions were made by maceration, adding methanol to the filtered bacterial cells from medium (intracellular extraction). $120 \mathrm{~mL}$ of methanol was added for each extraction. The liquid-liquid extraction and maceration processes were carried out in triplicate. Organic solvent was concentrated on a rotary evaporator (Model Q344B2, Quims, Diadema-SP, Brazil) where two types of extracts were obtained, from the culture medium and intracellular medium encoded as CV26AM30H, CV26AI30H, CV26BM30H and CV26BI30H for extraction of 30 hours and CV26AM40H, CV26AI40H, CV26BM40H and CV26BI40H for 40 hours extraction, according to table 01 . 
Table 1: Extracts obtained from bacterial cultures according to the time of cultivation and the place of extraction (medium or bacterial cells).

\begin{tabular}{llcc}
\hline Cultivation time & Substrate & \multicolumn{2}{c}{ Strains and their extracts } \\
\cline { 2 - 3 } & & CV26A & CV26B \\
\hline 30 hours & Culture medium & CV26AM30H & CV26BM30H \\
& Cells & CV26AI30H & CV26BI30H \\
40 hours & Culture medium & CV26AM40H & CV26BM40H \\
& Cells & CV26AI40H & CV26BI40H \\
\hline
\end{tabular}

\subsection{Cytotoxicity test by MTT reagent metabolization}

Samples of the 8 bacterial extracts identified in Table 1 were evaluated for their cytotoxic activity against murine fibroblast cells (line 3T3, Rio de Janeiro Cell Bank, code 0017) and murine melanoma (line B16F10, Rio Cell Bank de Janeiro, code 0342). Cells were seeded in 96 well plates at the $3 \times 10^{3}$ cells per well concentration. After 24 hours, the culture medium was removed and cells were treated with increasing bacterial extracts concentrations diluted in RPMI ${ }^{\circledR} 1640$ medium supplemented with $10 \%$ Bovine Fetal Serum (SFB), $100 \mu \mathrm{g} \mathrm{L}^{-1}$ of streptomycin and $100 \mathrm{IU} \mathrm{L}^{-1}$ of penicillin. 48 hours later, the cells were washed with culture medium and $100 \mu \mathrm{L}$ of a solution containing $0.5 \mathrm{mg} \mathrm{mL}^{-1}$ of the MTT reagent diluted in buffered saline (PBS) was added to the wells. After 2 hours, when it was possible to visualize the formazam crystals formed in the intracellular environment, MTT was removed and the formazam crystals were dissolved with acid isopropyl alcohol. The color formed was measured in a microplate spectrophotometer at $570 \mathrm{~nm}$ [19]. Negative control was performed with cells incubated with RPMI ${ }^{\circledR} 1640$ supplemented with $10 \%$ Bovine Fetal Serum (SFB), $100 \mu \mathrm{g} \mathrm{L}^{-1}$ streptomycin and $100 \mathrm{IU} \mathrm{L}^{-1}$ penicillin only. All samples were tested in quadruplicate and the assays were repeated at least on three different occasions for each bacterial extract.

\subsection{IC50 determination (Minimum Inhibitory Concentration)}

The extracts concentration which inhibits cell viability by $50 \%$ (IC50) was calculated using the GraphPad Prisma program, version 7.00 for Windows (GraphPad Software, La Jolla California USA, www.graphpad.com) following the tutorial provided by GraphPad Software, Inc, accessed March 18, 2019. The selectivity index (IS) was defined by the IC50 ratio of extracts between the non-tumor (3T3) and tumor (B16F10) lines. The data were subjected to normal distribution tests by Shapiro-Wilk and Bartlett, and subsequently analyzed by one-way ANOVA and Tukey posttest, with a significance level of $\mathrm{p}<0.05$. All tests were performed using the GraphPad Prism statistical software (version 7.00 for Windows, San Diego, California, USA).

\section{RESULTS AND DISCUSSION}

\subsection{Kinetic Study}

The growth curve projected with the 26 experiments made for the kinetic study (figure 1) were determined two ideal moments for obtaining bacterial extracts. After 30 hour of incubation, bacterial cells stopped the reproduction and start the stationary phase and, with 40 hours cells started decreasing (decline phase), according to Wang et al. (2015) [18] it is in these two moments that there is a greater metabolites production by the bacteria. The origin of these bacteria, a sandstone cave in the eastern Amazon, may be related to the delay in the log phase of the growth curves. In restrictive and highly competitive environments, microbial growth is slow and based on adaptations to ideal conditions [20]. 


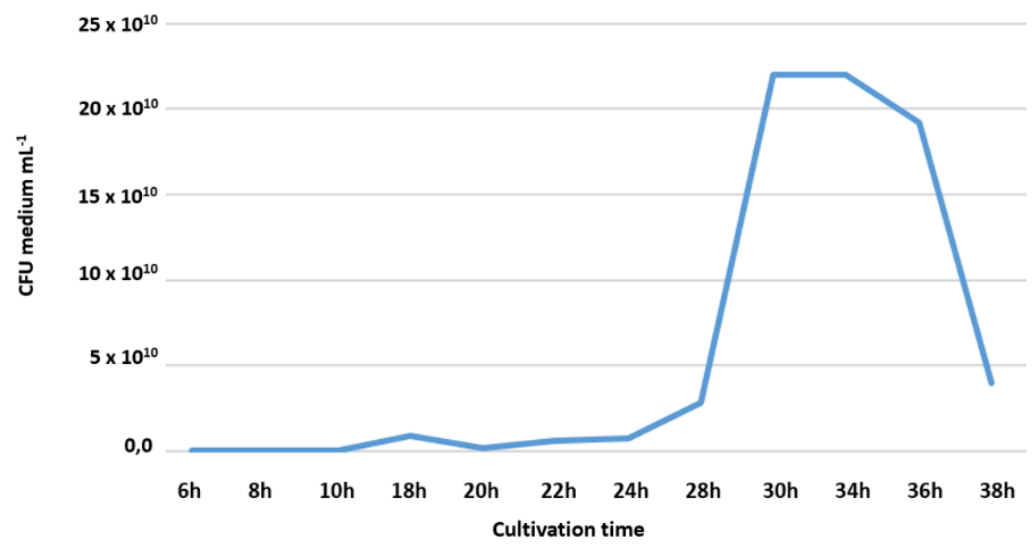

Figure 1: Bacterial growth curve of the kinetic study, the CFU measurement was started at 6 hours.

\subsection{Bacteria identification}

The isolated colonies obtained in cultivation showed a homogeneous aspect, with no contamination evidence. Microscopic analysis revealed the presence of gram-positive rods for the samples. Fragments of RNAr 16s from the samples, CV26A and CV26B, were successfully amplified and enlarged from their extracted genomic DNA. The sequences obtained from the rRNA16S region of the two strains compared to sequences deposited in the GenBank database showed similarities in the order of $99 \%$ and $100 \%$ with strains of Bacillus subtilis, although this is a strong indicator of the species, the fact of aligning with several subspecies does not make it possible to indicate only one and opens the possibility of new future identification. According to Nakamura et al. (1999) [21] and Rooney et al. (2009) [22], there is a group inside Bacillus subtilis with different characteristics, especially in the chemical way, not detected by the sequences of the RNAr 16S gene enough to create a new Bacillus specie. The environment from which the strains were isolated, a sandstone cave in a poorly studied region in microbiological terms of the Eastern Amazon, opens the prospect that these bacterial strains may fit into this group, and, in the future, by comparing other characteristics, may come to compose new subspecies or species.

\subsection{Anti-tumor tests}

From the analysis of the eight bacterial extracts listed in Table 1, CV26AI30H (Figure 2) and CV26AM40H (Figure 3) extracts showed the best result as they reduced the cell viability of the tumor line (B16F10) in a greater proportion than for the normal line (3T3) after a 72h of incubation.

With the $\%$ viability data obtained, the IC50 values were calculated for each extract (Table 2 ). According to Nalbantsoy et al. (2012) [23], the IC50 can be defined as the average concentration of an extract necessary to prevent $50 \%$ of cell growth considering at least three replications of an experiment. Thus, the lower the IC50, more active the substance is under a cell line. The $\mathrm{C} 26 \mathrm{I} 30 \mathrm{H}$ extract showed the lowest IC50 value for the tumor line B16F10, demonstrating to be the most promising extract for further studies.

Table 2: Values of the IC50 and selectivity index (IS) for control cells (3T3) and tumor cells (B16F10) of the bacterial extracts.

\begin{tabular}{cccc}
\hline Samples & Strains & $\boldsymbol{I C 5 0}(\boldsymbol{\mu g} / \boldsymbol{m} \boldsymbol{L})$ & $\boldsymbol{I S}$ \\
\hline CV26AM40H & B16F10 & 121,89 & 2,12 \\
CV26AM40H & $3 \mathrm{~T} 3$ & 229,10 & \\
CV26AI30H & B16F10 & 83,99 & $>4,70$ \\
CV26AI30H & $3 \mathrm{~T} 3$ & $>400$ & \\
CV26BM40H & B16F10 & 251,8 & 0,83 \\
CV26BM40H & $3 \mathrm{~T} 3$ & 209,8 & \\
CV26BI30H & B16F10 & $>400$ & 1,00 \\
CV26BI30H & $3 \mathrm{~T} 3$ & $>400$ & \\
\hline
\end{tabular}


The cytotoxicity comparison of the non-tumor with tumor cells (IC50 of extracts between nontumor and tumor lines) defined the selectivity index (IS), obtaining a value of 4.7 for tumor cell B16F10 in relation to $3 \mathrm{~T} 3$ for CV26AI30H extract. The Selectivity Index (IS) can be defined, according to Lopes et al. (2014) [24], as number of times that a substance is more toxic for one cell line than for another cell line. Thereby, a strong IS means that one substance is more cytotoxic than another. In cytotoxicity studies, a non-tumor lineage is generally used to be compared with tumor lineages, as this would propose a safety relationship in the component use. In our study, we compared the IC50 of the non-tumor line (3T3) with the IC50 of the melanoma line (B16-F10). Ayesh et al. (2014) [25] suggest that for a compound to be considered of low toxicity and with good chances of being a new anticancer drug, it must present an IS greater than 2. According to Fernandes (2015) [26], the IS value for a compound to be considered safe must be greater than 1, however, to be considered significant as an anti-tumor compound, this index must be greater than 2. Ganguly et al. (2018) [27] reported in their work a strong cytotoxic activity of Bacillus anthracis extracts against cancer cells with IC50 values of $64.5 \mu \mathrm{g} / \mathrm{mL}$.
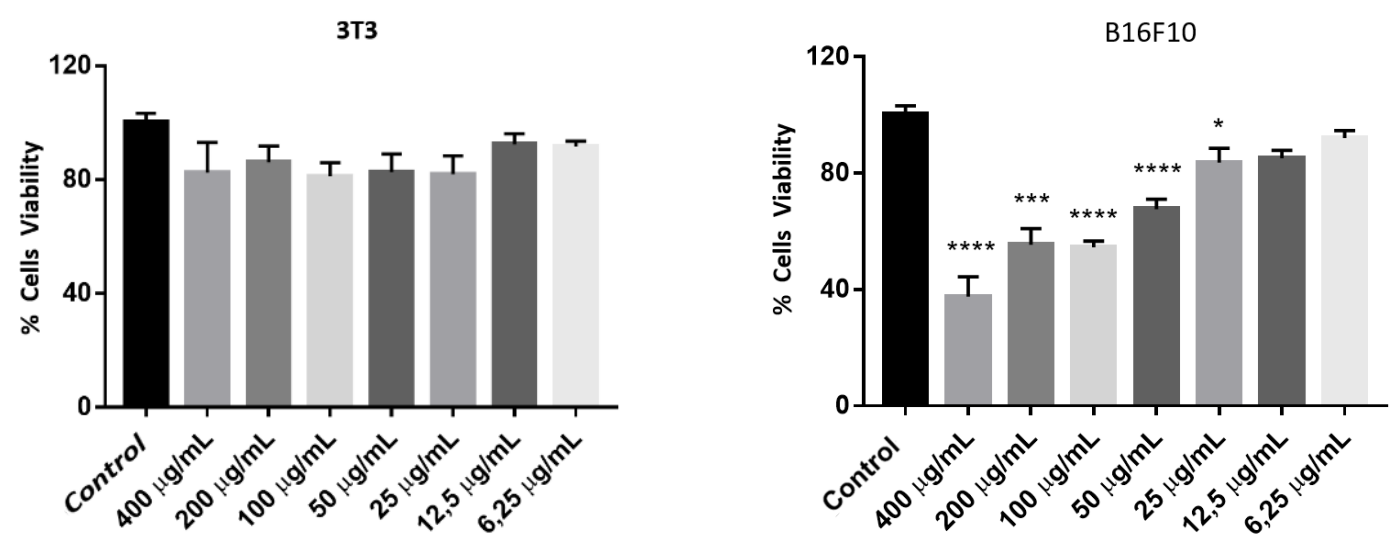

Figure 2: Viability of control cells (3T3) and tumor cells (B16F10) cultured in increasing concentrations of bacterial extract CV26AI3OH.
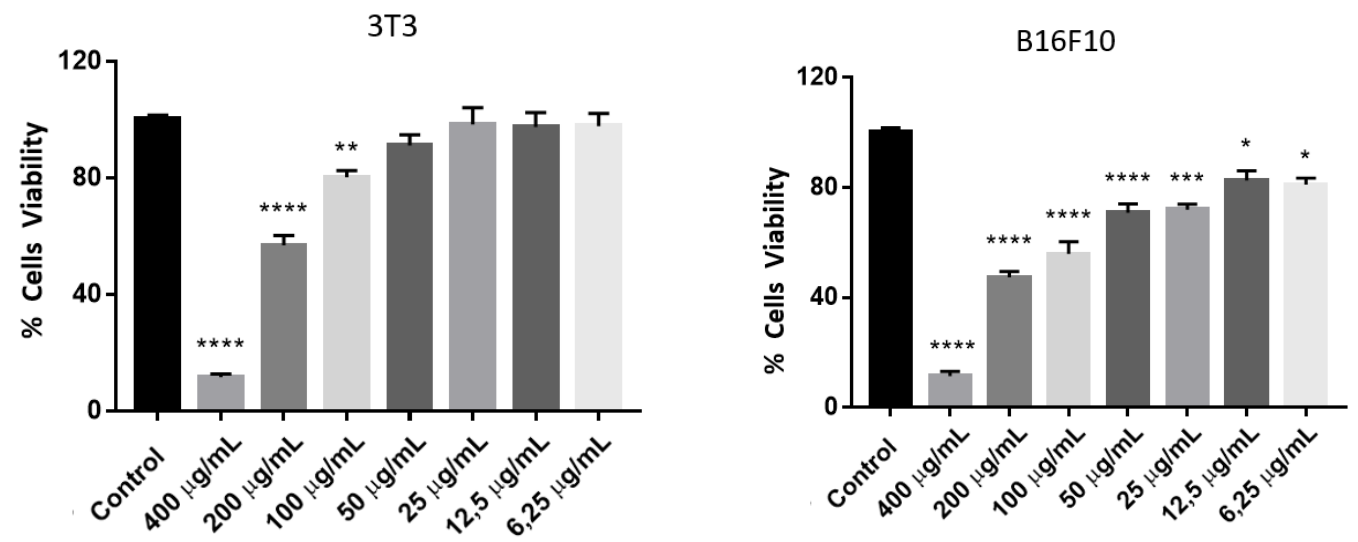

Figure 3: Viability of control cells (3T3) and tumor cells (B16F10) cultured in increasing concentrations of bacterial extract CV26AM4OH.

The CV26BM40H extract (Figure 4) was cytotoxic with IC50 from $100 \mu \mathrm{g} / \mathrm{mL}$, but with similar cell viability for two strains, both for the tumor (B16F10) and non-tumor (3T3). The CV26BI30H extract (Figure 5) presented IC50 greater than $400 \mu \mathrm{g} / \mathrm{mL}$ for both strains, being presented little cytotoxicity in the tested concentrations. 

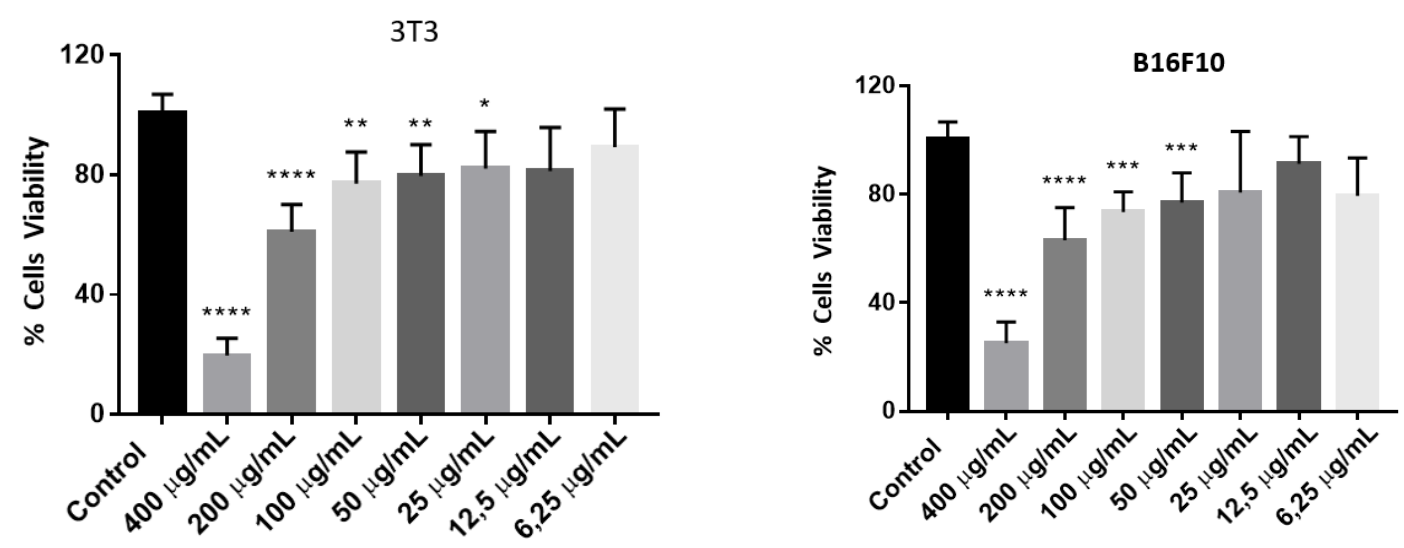

Figure 4: Viability of control cells (3T3) and tumor cells (B16F10) cultured in increasing concentrations of bacterial extract CV26BM4OH.
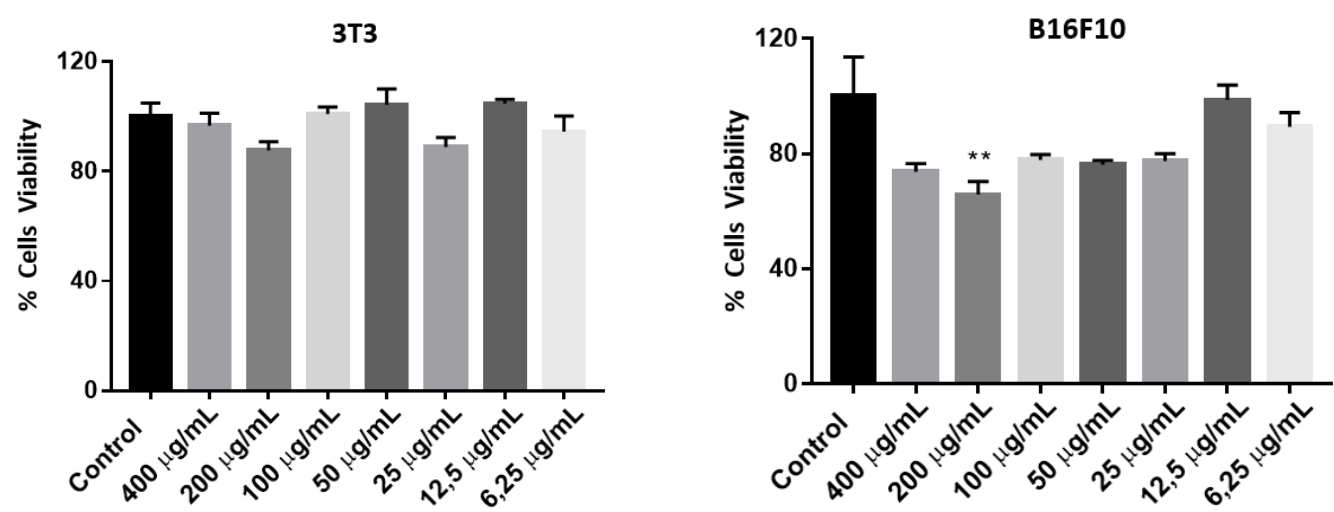

Figure 5: Viability of control cells (3T3) and tumor cells (B16F10) cultured in increasing concentrations of bacterial extract CV26BI3OH.

The difference in the IC50 values and selectivity index observed between species extracts of C26A and CV26B (Figures 2, 3, 4 and 5) may be one more evidence that we have two different species, since the extracts went through the same preparation and treatment process. Active principles of cellular toxicity reside in the bioactive metabolites of extracts, whether those of microorganisms or plants. As a result, several studies have been carried out with crude extracts against cancer cells searching compounds with excellent IC 50 values, such as the heptapeptide and azurine compounds, isolated from the Paenibacillus profundus and Pseudomonas aeruginosa bacteria, with IC50 of 3.07 $\mu \mathrm{M}$ and $32-53 \mu \mathrm{M}$ against cancer cells, respectively [28-29]. There are currently several studies abough cave microorganisms, with a focus on finding biologically active compounds. Within this theme there are reports of actinobacteria with antibacterial, antifungal and anticancer activity [9,30], Nakaew and collaborators also reported activities on some cancer cells of a new actinomycete belonging to the genus Nonomuraea sp. (PT708) [31]. Thus, this study corroborates the search for anticancer bioactive compounds, since the results obtained here have shown promise with the tumor cell B16F10. The other results described for the Bacillus genus in caves, demonstrate only antibacterial and antifungal activities.

Considering that in this study, positive results were obtained with extracts from intracellular phase, it is believed that the active substances may be an endogenous molecule of bacterial cells of $B$. subtillis species. Thus, it becomes viable to carry out a extraction process and purification of these metabolites later, using ultrafiltration and microfiltration membranes, since these processes are highly viable in obtaining active compounds. This study will not only allow isolation of the 
active compound (s) to be isolated, but also will be able to differentiate the CV26A and CV26B species, based on their chemical profile, corroborating with their identification.

\section{CONCLUSION}

The study with the bacterium B. subitilis isolated from the Pedra da Cachoeira cave made possible to evaluate different chemical extracts against the cancer cells and as they are crude extracts, the IC50 values obtained show that these microorganisms are promising for active compounds production, mainly the CV26AI30H extract. This extract provided a "in vitro" IC50 with a 83.99 value and a 4.70 selectivity index, satisfactory results that encourage the search for new bioactive compounds against cancer cells. That is, compounds with significant selectivity for B16F10 melanoma cells and little cytotoxic against healthy cells.

\section{ACKNOWLENGMENTS}

The authors are grateful to the PPGQ - Postgraduate Program in Chemistry from the Universidade Federal do Sul e Sudeste do Pará and the Laboratory of Cell Biology and Protozoology on the Universidade Estadual de Ponta Grossa - PR.

\section{REFERENCES}

1. Bray F, Ferlay J, Soerjomataram I, Siegel RL, Torre LA, Jemal A. Global Cancer Statistics 2018: GLOBOCAN estimates of incidence and mortality worldwide for 36 cancers in 185 countries. CA: A Cancer Journal for Clinicians. 2018 Sep;68(6):394-424, doi: 10.3322/caac.21492.

2. Piñeros M, Znaor A, Mery L, Bray F. A global cancer surveillance framework within noncommunicable disease surveillance: making the case for population-based cancer registries. Epidemiologic Reviews. 2017 Jan;39(1):161-169, doi:10.1093/epirev/mxx003.

3. Munhoz MP, Oliveira J, Gonçalves RD, Zambon TB, Oliveira LCN. Efeito do exercício físico e da nutrição na prevenção do câncer. Revista Odontológica de Araçatuba. 2016 May;37(2):34-40.

4. Aguiar PNJR, Stock GT, Lopes GL Jr, Almeida MS, Gutierres BS, Rodrigues DA. Disparidades na epidemiologia no tratamento de câncer nas populações indígenas brasileiras. Revista Creative Commons. 2106 Jul;14(3):330-337, doi: 10.1590/S1679-45082016AO3754.

5. Karpinski TM, Adamczak A. Anticancer activity of bacterial proteins and peptides. Pharmaceutics. 2018 Apr;10(2):54-80, doi:10.3390/pharmaceutics10020054.

6. Hu D, Chen Y, Sun CG, Fan TJ, Liao GQ, Mok KM, Lee MS. Genome guided investigation of antibiotics producing actinomycetales strain isolated from a Macau mangrove ecosystem. Scientific Reports. 2018 Sep;8:14271, doi: 10.1038/s41598-018-32076-z.

7. Crusemann M, Neill ECO, Larson CB, Melnik AV, Floros DJ, Silva RR, Jensen PR, Dorrestein PC, Moore BS. Prioritizing natural product diversity in a collection of 146 bacterial strains based on growth and extraction protocols. J Nat Prod. 2017 Nov;80(3):588-597, doi: 10.1021/acs.jnatprod.6b00722.

8. Marques ELS, Correia DC, Oliveira RBF, Silva KB, Dias JCT, Pirovani CP, Rezende RP. Potencial biotecnológico de microrganismos isolados de cavernas de Paripiranga, Bahia. In: Rasteiro MA, Sallun FW, organizers. Anais do $33^{\circ}$ Congresso Brasileiro de Espeleologia; 2015 Jul 15-19; Eldorado, SP, Brazil. Campinas (SP): SBE; 2015. p. 161-168.

9. Ghosh S, Kuisiene N, Cheeptham N. The cave microbiome as a source for drug discovery: Reality or pipe dream? Biochem Pharmacol. 2016;134:18-34. doi: 10.1016/j.bcp.2016.11.018

10. Trajano E, Moreira JRA. Estudo da fauna de cavernas da província espeleológica arenítica AltamiraItaituba, Pará. Rev Bras Biol. 1991;51(1):13-29.

11. Nunes JA, Nascimento GA, Nascimento RA, Correia MS, Araújo DM, Albino U. Antibiose por bactérias de caverna arenítica da Amazônia oriental. In: Rechenchoski DZ, editor. Anais do I Congresso Paranaense de Microbiologia; 2014 Ago 04-06, Londrina, PR, Brazil. Londrina (PR): SBM; 2014. p. 120-122.

12. Aamir S, Sutar S, Singh SK, Baghela A. A rapid and eficiente method of fungal genomic DNA extraction, suitable for PCR based molecular methods. Plant Pathology \& Quarantine. 2015 Dec;5(2):74-81, doi: $10.5943 / \mathrm{ppq} / 5 / 2 / 6$.

13. Thompson JD, Gibson TJ, Plewniak F, Jeanmougin FD, Higgns DG. The Clustalx Windows interface; flexible strategies for multiple sequence alignment aided by quality analysis tools. Nucleic Acids. 1997 Dec;25(24):4876-4882, doi: 10.1093/nar/25.24.4876. 
14. Hall TA. BioEdit: A user-frendly biological sequence alignment editor and analysis program for Windows 95/98NT. Nucleic Acids Symposium. 1999 Jan;41:95-98, doi:10.14601/Phytopathol_Mediterr14998u1.29.

15. Tamura K, Steecher G, Peterson D, Filipski A, Kumar S. Mega6: Molecular evolucionary genetcs analysis version 6.0. Mol Biol Evol. 2013 Dec;30(12):2725-2729, doi:10.1093/molbev/mst197.

16. Kimura MA. A Simple model estimating evolutionary rates of base substitutions through comparative studies of nucleotide sequences. J Mol Evol. 1980 Jun;16(2):111-120, doi: 10.1007/BF01731581.

17. Saitou N, Nei M. The neighbor-joining method: a new method for recontructing phygeonetic trees. Molecular Biology and Evolution. 1987 Jul;4(4):406-425, doi: 10.1093/oxfordjournals.molbev.a040454.

18. Wang L, Fan D, Chen W, Terentjev EM. Bacterial growth, detachment and cell size control on polyethylene terephthalate surfaces. Sci Rep. 2015 Oct;5:15159, doi:10.1038/srep15159.

19. Mosmann T. Rapid Colorimetric assay for cellular growth and survival: application to proliferation and cytotoxicity assays. J lmmunol Methods. 1983 Dec;65(1-2):55-63, doi: 10.1016/0022-1759(83)90303-4.

20. Yiyi D, Jie G, Qingshan W, Yilang A, Yu H, Wenzhang W, Shiyu S, Qingbei W. Co-occurrence pattern and function prediction of bacterial community in Karst cave. BMC Microbiology. 2020 May;20(1):113, doi: 10.1186/s12866-020-01806-7.

21. Nakamura L, Roberts M, Cohan F. Relationship of Bacillus subtilis clades associated with strains 168 and W23: a proposal for Bacillus subtilis subsp. Subtilis subsp. nov. and Bacillus subtilis subsp. Spizizenii subsp. nov. Int J Syst Bacteriol. 1999 Jul;49(Pt 3):1211-1215, doi: 10.1099/00207713-49-3-1211.

22. Rooney A, Price N, Ehrhardt C, Swezey J, Bannan J. Phylogeny and molecular taxonomy of the Bacillus subtilis species complex and description of Bacillus subtilis subsp Inaquosorum subsp nov. Int J Syst Evol Microbiol. 2009 Oct;59(Pt 10):2429-2436, doi: 10.1099/ijs.0.009126-0.

23. Nalbantsoy A, Karabay-yavasoglu NU, Deliloglu-gurhan I, Gocmen B, Arikan H, Yildiz MZ. Determination of in vivo toxicity and in vitro cytotoxicity of venom from the Cypriot blunt-nosed viper Macrovipera lebetina lebetina and antivenom production. J Venom Anim Toxins incl Trop Dis. 2012 Feb;18(2):208-216, doi: 10.1590/S1678-91992012000200011.

24. Lopes EO, Oliveira CG, Deflon VM, Leite CQ, Pavan FR. Determinação da atividade antitumoral in vitro dos complexos de coordenação contendo os metais Zn(II) e Co(III). Rev Ciênc Farm Básica Apl. 2014 Aug;35(Supl 1):1.

25. Ayesh BM, Abed AA, Faris DM. In vitro inhibition of human leukemia HP-1 cells by Origanum syriacum L. and Thymus vulgaris L. extracts. BMC Res Notes. 2014 Sep;7(7):612, doi: 10.1186/1756-0500-7-612.

26. Fernandes TB. Planejamento, síntese e avaliação do potencial antitumoral de compostos arilsulfonilhidrazônicos. São Paulo (SP): Universidade de São Paulo; 2015. 172 p.

27. Ganguly RK, Midya S, Chakraborty SK. Antioxidant and anticancer roles of a novel strain of Bacillus anthracis isolated from vermicompost prepared from paper mill sludge. BioMed Res Int. 2018 Aug;2018:1073687, doi: 10.1155/2018/1073687.

28. Kalinovskaya NI, Romanenko LA, Kalinovsky AI, Dmitrenok PS, Dyshlovoy SA. A new antimicrobial and anticancer peptide producing by the marine deep sediment strain "Paenibacillus profundus" sp. nov. S1 79. Nat Prod Commun. 2013 Mar;8(3):381-384, doi: 10.1177/1934578X1300800326.

29. Goto M, Yamada T, Kimbara K, Horner J, Newcomb M, Gupta TK, Chakrabarty AM. Induction of apoptosis in macrophages by Pseudomonas aeruginosa azurin: Tumour-suppressor protein p53 and reactive oxygen species, but not redox activity, as critical elements in cytotoxicity. Mol Microbiol. 2003 Jan;47(2):549-559, doi: 10.1046/j.1365-2958.2003.03317.x.

30. Rangseekaew P, Pathom-aree W. Cave actinobateria as producers of bioactive metabolites. Frontiers Microbiol. 2019 Mar;10:387, doi: 10.3389/fmicb.2019.00387.

31. Nakaew N, Sungthong R, Ortega-Calvo JJ, Lumyong S. Antibiotic activity and anticancer of a new Nonomuraea sp. strain PT708 originated from Thai cave soil. Microbes in applied Research. 2012 Aug:474-480, doi: 10.1142/9789814405041_0096. 